\title{
Student's Conceptual Mindfulness about Learning Pronunciation at College Level
}

\author{
Asma Saman \\ M.Phil. (Scholar) \\ The University of Lahore \\ Lahore, Pakistan \\ samanasma045@gmail.com
}

Muhammad Qasim Ali

$\mathrm{PhD}$ (Scholar)

The Islamia University of Bahawalpur

Bahawalpur, Pakistan

qasimvr@yahoo.com

Dr. Najam Ul Kashif

Assistant Professor

The Islamia University of Bahawalpur

Bahawalpur, Pakistan

najamulkashif@gmail.com

Abstract 
The study highlights students' conceptual mindfulness about learning pronunciation at college level. The objective of the study were; 1) to find out the usefulness of English language pronunciation among college students, 2) to highlight students' problems in the way of learning English pronunciation at college level and 3) to find out the perceptions of students toward English pronunciation competence at college level. It was a descriptive study and questionnaire was used as a research tool. All the college students in the three districts (Okara, Pakpattan \& Sahiwal) were included in the population. Fifty college students took from each district through simple random sampling techniques. So, the total sample of the study was 150 college students from three districts. Data was analyzed and find the mean score value for all the statement and then marked the mean score value with Levels of opinion. The results of the study informed us that learning the pronunciation of the $2^{\text {nd }}$ language is difficult but not impossible; little concentration, practice and hard work is required to learn pronunciation of English language. It is concluded that four integrated skills; reading, listening, writing and speaking should be used in the teaching learning process for pronunciation and also used the 'listen and repeat' technique should be used.

Keywords: Perceptions, Problems, Pronunciation, EFL Learners.

\section{Introduction}

In United States and United Kingdom English is spoken as a first language by more than three-hundred-forty (340) million people (Crystal, 1997). But in educational system of Pakistan English has remained a subject of controversy. Celce-Murcia, Brinton and Goodwin (1996) states that correct pronunciation paves the way for effective communication. The quality of communication is influenced by the both parties of the speaker and the listener. Moreover, about acquisition of speech sounds, Chomsky (1972) claims that spoken 
communication deals with the proficiency determined on the correct use of segmental and supra-segmental features.

In this technological era, teachers should provide ICT gadgets to the students for the improvement in learning pronunciation. Better pronunciation can be learned in student centered classroom. In our secondary and higher secondary schools, there are teacher centered classrooms. So, learners' perceptions have been ignored by the researchers (Kang, 2010). Pronunciation plays an important role in effective communication. It is included in English course but it is omitted in lesson plans, and often students are enforced to learn English pronunciation by perception. In order to develop understanding, speaker should use English language proficiently. For that reason, it is essential to teach pronunciation. Teachers have ignored its importance and that's why there is no progress in the area of teaching and learning pronunciation.

If speakers or learners have good pronunciation, they can easily be understood by others even after making some errors, however, speakers or learners with poor pronunciation even after having perfect grammar will not be understood by the hearer. For this reason, speakers or learners lose their self-confident and find difficulties while speaking English. They face problems in further studies and employment. Generally, learners with bad pronunciation are considered as incompetent. Therefore, the learners find it difficult to learn English language with correct pronunciation and ask teachers for help. English is used almost all over the world and in order to develop understanding we cannot communicate without using language. Even after years of learning English language learners' face major problems with English pronunciation. Despite of its significance, the teaching of pronunciation in the area of English language learning has been ignored by teachers.

Teachers have always made lame excuse that they are teaching pronunciation proficiently, but in actual they are unenthusiastic, unwilling and hesitant in using English 
inside and outside the classroom. They do not found enough time for teaching of pronunciation. That's why students are passive and have limited knowledge in English language.

According to Warsi (2004) English teachers in Pakistan have shown very little satisfaction towards teaching English pronunciation. Additionally, he points out that English is used as a lingua franca in Pakistan and plays a fundamental role. In Pakistan students belong to rural areas. English language is being taught for about eight years in schools. Students with no background knowledge in English language are incompetent. In Pakistan English is used and spoken as a third language for them besides Urdu and other regional languages (Warsi, 2004). Due to this situation of English language in Pakistan, the status of poor pronunciation can simply be imagined.

In $3^{\text {rd }}$ world countries, students as well as masses learn the dominant languages as the English language just for the completion of academic level or for prestigious. Negligence has been found from the start of the academic world. Every aspect of learning English language should be given emphasis to but pronunciation has been neglected by the teachers as well as the students. Morley (1991) claims that negligence in teaching pronunciation has been found at higher education level. So, the purpose of the study is to explore the perceptions of students regarding learning pronunciation at college level. The objectives of the study are in the following lines.

Objectives of the study

The objectives of the study were:

1. To find out the usefulness of English language pronunciation among college students.

2. To highlight students' problems in the way of learning English pronunciation at college level. 
3. To find out the perceptions of students toward English pronunciation competence at college level.

\section{Review of related Literature}

Effective communication is a key to success. While the older pronunciation textbooks usually focused on sound discrimination. This is one of the myths held by many teachers and students and that's why ignored as well. This field of study demands attention of the teachers and students. According to Krashen's idea, students should acquire language instead of learning a new language. Further Krashen (1986) explains that acquiring a language is a natural process and it's as same as acquiring first language. On the contrary, Pakistani students learn English merely to memorize vocabulary and grammar.

Howlader (2010) made a research and recommended training on English pronunciation. The results showed that the perspectives of Bangladeshi participants were pessimistic, but they are trying to develop improvement in learning English. It is suggested that oral communication should be improved with the contribution of mutual intelligibility, accent and comprehensibility. Moreover, Goswami, Jaya, and Chen (2010) made a research on the Spanish speakers. An experiment was made on the selected participants. They were delivered the lectures in English language to teach them accurate pronunciation by using modern techniques. By keeping in view that with the help of the involvement of senses like seeing, hearing and listening they can remember the pronunciation of English sounds more proficiently. The results of the study show that intervention of first language in teaching second language affects the learning of pronunciation to a great extent. The reason behind is that teachers practiced the code switching technique which made the students and learners double minded and confused them as well. 
Khamkhien (2010) conducted a research on English as an international language and states that inaccurate pronunciation is a block in developing decent communication. Instead of contribution of other factors like grammar and vocabulary; incorrect pronunciation is distressing the implication of communication. The researcher examined 90 Thai students and found that the selected subjects were facing the same problem in learning pronunciation. The findings of the study showed that students want their teachers to get well exposed this field of study in front of them. It is suggested that courses should be provided to them with complete guidance of the teachers so that they can develop command over this language with accurate pronunciation.

Likitrattanaporn (2014) made a research and find out that testing system is an imperative method with the help of which not only students will learn pronunciation but will develop far significant place in their academic career by earning highest grades. With the help of this system teachers can grab the attention of the students and can develop competition in students for giving their best outcomes. It is suggested that with the help of this, students will not only practise this field of study but will try to improve their language skills.

Pronunciation paves the way for developing mutual understanding and effective communication. This field of study demands the attention of the whole education department. It is suggested that teachers and students should give their time and attention to this aspect of language. Such as, Esmail, Ahmed and Noreen (2015) assert that English language is generally used in the academic world and English is widely used by the different departments. Students should practice pronunciation to be competent in developing understanding and effective communication. Students should actively take part in learning English language. 
Factors Affecting Learning Pronunciation

The factors that affect the learning of pronunciation are discussed as;

\section{Motivation and Exposure}

In addition with stage of development at receiving second language, motivation is a building block. If learners want to achieve and learn native-like pronunciation motivation plays an important role with the well exposure of target language. Subjective as well as proficient objective affect the necessity in addition to aspiration in leaning the native-like accent of second language (Gatbonton, Trofimovich, \& Magid, 2005). Marinova-Todd, Marshal, \& Snow (2000) reviewed a research on acquisition of English language and determined that if adults are encouraged and motivated to do, they can produce effective communication. Moyer (2007) found that in order to develop native-like pronunciation, knowledge and understanding in addition to optimistic alignment seems to be the most imperative aspect. For that reason, teachers should motivate students in accumulation and articulation of speech sounds, instructors should motivate English as a foreign language learner to communicate English outdoor and should exchange their thoughts and made them practice.

\section{Exposure to Target Language}

English is not only learned as a subject but also as a language from the childhood. As compared to English medium schools, the students who belong to Urdu medium schools have less exposure to English language. They have insufficient background knowledge and are incompetent in English language. Learning a language and speaking a particular language are opposite to each other and are two sides of the same coin, as same is the difference between a theory and its practical. For this reason, eloquent exposure to English language is acquired. 
Various activities should be practiced in order to have better exposure to target language with the help of exchange of communication. Oral communication should be used and practiced effectively. Vocal communication involves those features of speech that are non-linguistic components. These features demand exposure to target language because they are not learned from the course books. These features add in the meaning of the words and made them more meaningful to be understood easily. Gestures, facial expressions and body language are the supra-segmental features and demand exposure. These features of speech are instructed by the teachers experienced in daily life situations.

\section{Mother Tongue Intervention.}

Avery and Ehrlich (1992) claim that the transmission and intervention of mother tongue into the target language results in foreign accent. False pronunciation by non-native speakers reflects the impression of their first language. For example, in a number of studies the development and impact of English aspects was examined in non-native speakers' (Wenk, 1985). So it can be concluded that such transmission can stimulate the learners' pronunciation, which is not a part of learners' sound inventory, or in other words beginners perhaps not be capable to generate or recognize the sound(s). Additional, the combination of sounds into words (i.e., phonotactic instructions) in the native and non-native language are totally different and result in obstacles for beginners for the reason that these differences are language specific and differ from one to another. Lastly, learners may make over the patterns of stress and intonation into the target language. In summary, the aspects revised overhead may assist EFL learners' and teachers' to recognize the problems faced by the non-native learners' in the pronunciation (Graham, 1994). These activities not only develop awareness in the students but also in the teachers and would facilitate the both in this field of study. The needs of the students have now changed so teachers should develop new strategies according 
to their demands. Mostly, the teachers and students switch to their first language for their ideas.

Research Procedure

The present study was conducted to find out college students' perceptions about the three aspects of pronunciation: Usefulness of English language pronunciation, problems in the way of learning English pronunciation and students' English pronunciation competence. The study was conducted in three districts (Pakpattan, Okara \& Sahiwal) to get the perceptions of college students about learning English pronunciation. So, it was a descriptive research study. The population of the study comprised all the male students studying in the public colleges of three districts i.e. Pakpattan, Okara and Sahiwal. Sample of the study were collected from two colleges from each district. Researchers used simple random sampling technique to collect data from the respondents. It was decided that 50 students were taken from each district.

Questionnaire was used for the study to collect data from the said respondents because questionnaire is the best tool to get perceptions from the sample of the study in descriptive researches. The questionnaire items were developed through reviewing the related literature. Researchers developed questionnaire on five-point likert scale from strongly agree to strongly disagree. It was developed 54 items for the questionnaire but after checking the validity and reliability of the questionnaire; at last 30 items were finalized for the questionnaire. To gauge the internal consistency of the research tool the extensively used Cronbach's Alpha Coefficient was used, the value of the Alpha was 0.75.

Data was collected from the six colleges; thirty questionnaires were distributed among EFL learners. So, the researchers collected 180 filled questionnaires from the respondents and selected 150 questionnaires that are appropriately and completely filled for analysis. Simply, 
mean score technique was used to interpret the data. The level of opinions of the respondents was charted as;

Table No. 1

Level of Opinions

\begin{tabular}{cc}
\hline Levels of Opinion & Mean Score Value \\
\hline Highest & $4.50-5.00$ \\
Higher & $3.50-4.49$ \\
Average & $2.50-3.49$ \\
Lower & $1.50-2.49$ \\
Lowest & $0.00-1.49$
\end{tabular}

Data Analysis and Interpretation

The analysis and interpretation of the data is given below.

Table No. 2

Usefulness of English Language Pronunciation

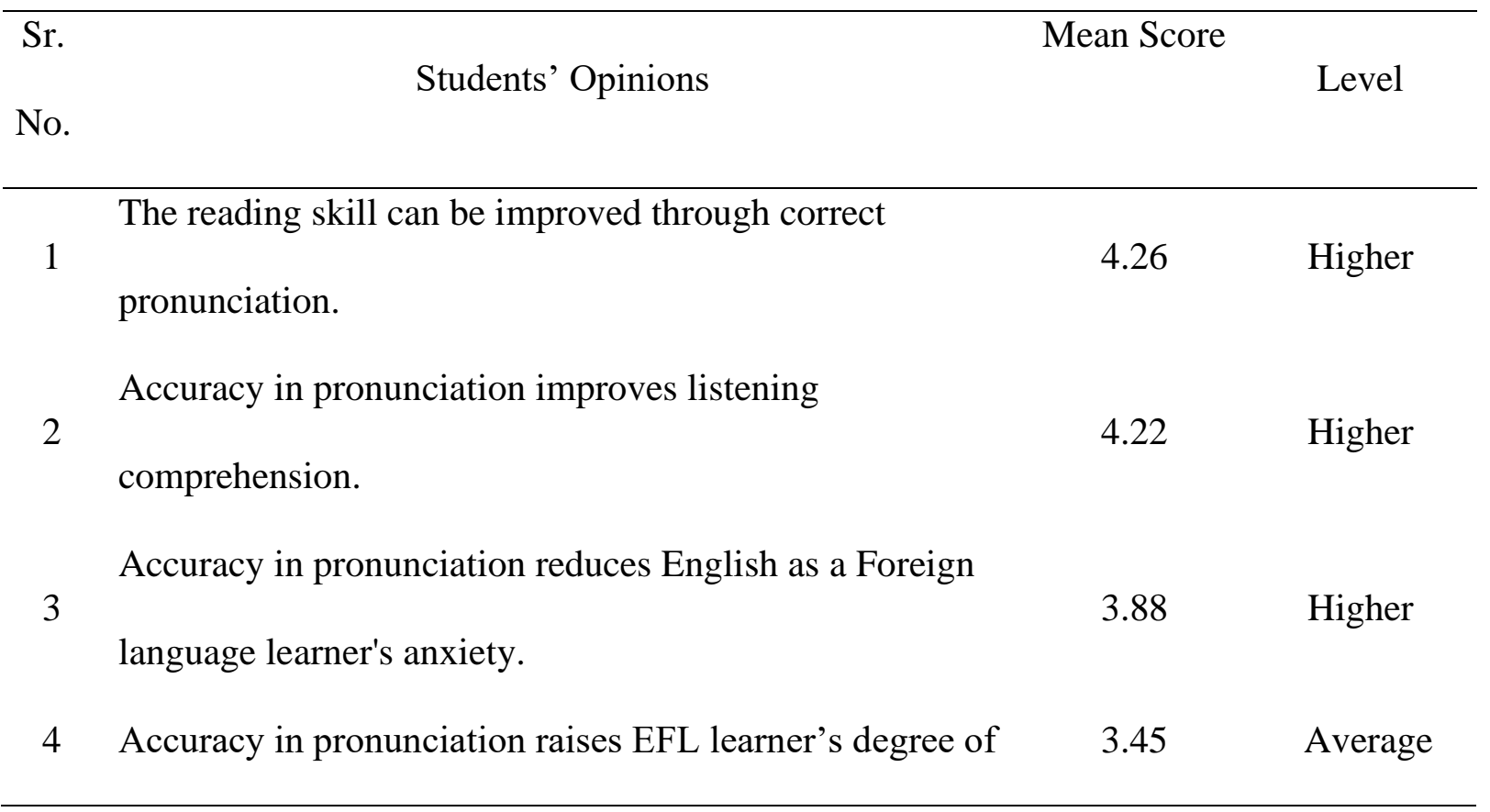


self-confidence

5

EFL learner's poor pronunciation influences his/her

ability to communicate.

English language learning is a motivating factor in having

6 a standard pronunciation

7 Accuracy in pronunciation makes communication easier.

One's knowledge can be judged by his/her good or poor

8 pronunciation.

9 Accuracy in pronunciation appeals to the listener.

10 Accuracy in pronunciation indicates one's personality
Higher

2.92

Average

4.46

Higher

Highest

3.53

Higher

3.80

Higher

The statement 1 of table 2 is to gauge the perception of students, if reading skill can be improved through correct pronunciation. The mean score 4.26 shows the higher level of agreement of students and teachers as well on the same item. The results show that reading can be used as a tool for the improvement of correct pronunciation. Practice makes a man perfect and with the help of this accuracy can be developed in communication. In statement 2, 3 and 4 when students were asked about aspects related to accuracy in pronunciation as it improves listening comprehension, reduces learners' anxiety as well as raises learners' degree of self-confidence the students and the teachers show highest level of agreement with the mean score on the 2nd statement is 4.22 . The students' perception on the 3rd statement with the mean score of 3.88 shows the difference of opinion between the viewpoints of teachers and students on the same statement. The statement 4 shows the responses of students with the mean score of 3.45 and 3.60 of teachers respectively having the difference of 0.15 . The results of the statement 2, 3 and 4 shows that pronunciation is the key to success with the help of accurate pronunciation many problems can be solved in the area of listening skills, in developing confidence and also in developing enthusiasm in students for the learning of 
English language. This reveals and throws light on the importance of correct pronunciation. Cenoz and Lecumberi (1999) findings show that pronunciation is considered an important and difficult skill. Learners' report that in order to learn correct pronunciation phonetic and contact with native speakers is the most persuasive. The question 5 is to explore the importance of pronunciation while asking students about the influence of poor pronunciation on effective communication. The mean score 2.92 shows the average level of agreement of the students and teachers on the same statement. The background of the subjects was near to the ground. They have limited syntactic structures and vocabulary. That's why they have no experience understanding and are less exposed to this language. In statement 6 , this view point is supported when students were asked that English language learning is a motivating factor in having a standard pronunciation. The students' show average level of agreement on the statement with the mean score 2.92. The result shows that learning English language with correct pronunciation is not an easy task. This reveals the fact that students are facing difficulties even after knowing the importance of learning English language and showing least interest on this statement. Conversely, on statement 7 when students were asked that accuracy in pronunciation make communication easier. The students show the higher level of agreement with the mean score of 4.46 as of teachers. The statement 8 is to find out the students perception on one's knowledge with the help of pronunciation. The mean score of this statement is 4.79 . The result shows that students were of the view that pronunciation has significant importance and with the help of proficient pronunciation one's knowledge can be judged as well. The statement 9 and 10 is to extract out the importance of accuracy in pronunciation. The mean score 3.53 while asking accuracy in pronunciation appeals to the listener and 3.80 asking accuracy in pronunciation indicates one's personality. With the help of the results obtained from the data it is self-evident that in order to survive in this present age and to earn bread and butter a person should well-known the segmental and 
non-segmental features of pronunciation. According to Rajadurai (2001) segmental areas of pronunciation are focused as compare to supra segmental features. According to him explicit teaching of supra segmental areas of pronunciation offers enhanced intelligibility and comprehension. In conclusion, both of segmental and supra segmental areas of teaching give momentous outcome in affecting students' pronunciation.

Table No. 3

Problems in the way of Learning Language Pronunciation

\begin{tabular}{|c|c|c|c|}
\hline $\begin{array}{l}\text { Sr. } \\
\text { No. }\end{array}$ & Students' opinions & $\begin{array}{l}\text { Mean } \\
\text { Scores }\end{array}$ & Level \\
\hline 1 & $\begin{array}{l}\text { EFL learners' face problem in pronunciation due to } \\
\text { lack of knowledge }\end{array}$ & 4.87 & Highest \\
\hline 2 & $\begin{array}{l}\text { EFL learners' face problem in pronunciation due to } \\
\text { unavailability of Audio Visual aids in the } \\
\text { classroom. }\end{array}$ & 4.76 & Highest \\
\hline 3 & $\begin{array}{l}\text { Due to theoretical course, EFL learners' face } \\
\text { problems which doesn't support them in improving } \\
\text { pronunciation. }\end{array}$ & 2.40 & Average \\
\hline 4 & $\begin{array}{l}\text { Objective of learning English is just to get good } \\
\text { marks in the examination. }\end{array}$ & 3.31 & Average \\
\hline 5 & $\begin{array}{l}\text { EFL learners' face problem due to Mother tongue } \\
\text { influence on learning English Pronunciation. }\end{array}$ & 3.26 & Average \\
\hline 6 & $\begin{array}{l}\text { More stress is on learning grammar to improve } \\
\text { writing skill and not on pronunciation. }\end{array}$ & 4.50 & Highest \\
\hline 7 & Teachers use translation method for learning & 2.61 & Average \\
\hline
\end{tabular}




\section{English.}

EFL learners' do not participate in group discussion

8 with poor pronunciation, are afraid of being laughed

Lowest

at.

Students lack relevance between correct

pronunciation and reading comprehension, while

Average reading a text.

The way words are pronounced, are irrelevant to their spellings in English language.

In statement 1, 2 and 3 of table 3 is that the students were asked about their problems in learning pronunciation due to lack of knowledge, non-availability of Audio Visual aids in the classroom and due to theoretical course which doesn't support them in improving pronunciation. The students' show their highest and average level of agreement on the levels of opinion with the mean score of $4.87,4.76$ and 2.40 respectively. The perceptions of teachers were quite different on the same items. The result shows that students were facing problems in learning pronunciation because most of them belong to rural areas and English language is very difficult for them. Learning a new language with accurate pronunciation is not an easy task for them, therefore, they are afraid of giving their opinions and feel shy. Major (1987) mentions some advantages of the modern techniques and recommends modern and computerized techniques in order to measure pronunciation accuracy. The statement 4 is to explore out that the objective of learning English is to get good marks in the examination. The mean score 3.31 shows average level of agreement of the students on the statement showing the difference in perceptions of teachers with the mean score 1.00 on the same statement. The results show that they learn English because they want to earn good grades in their subjects. This reveals that they like to use Urdu language and do not try to use English 
for communication purposes outside the classroom. Scores of researches claim that students after getting education for eleven years in English language: are incompetent and less proficient. In statement 5, the students were asked that they face problem due to influence of mother tongue on learning English pronunciation, they show average level of agreement on the statement with the mean score of 3.26 as compare to the higher level of agreement of teachers on the same item. This shows that students usually chat with their friends in their mother tongue and feel it more convenient as compare to English language and they do not even try to use English language in their communication. The statement 6 is to find out the perceptions of students' while asking that teachers' more stress is on teaching and learning grammar and not on pronunciation. The mean score for question 6 is 2.30 of students and 4.30 of teachers with the difference of mean score 2.00. The result shows that the students were going through difficulties and facing a lot of problems in learning grammar, but they were showing their interest as well. Learning a new language is not only their goal, but they also wanted to completely master over this language with the help of accurate pronunciation. In the statement 7 students accept this concept that teachers use translation method for learning English with the mean score of 2.61 and 4.61 of teachers with the difference of mean score 2.00. This shows the difference of opinions between teachers and students of public colleges. This is because students' get less exposure to English language. It reveals that teachers should make changes in their methods of teaching English language. The statement 8 is to gauge the perceptions of students that they do not participate in the group discussion with poor pronunciation because they are afraid of being laughed at them by other students. They show lowest level of agreement with the mean score of 1.38. The result shows that the students have limited background knowledge in English language but they do participate in group discussions. This reveals the fact that students were taking an active part in learning accurate pronunciation. The question 9 is to find out the perceptions of students about lack of 
relevance between correct pronunciation and reading comprehension, while reading a text. The result with mean score 3.32 shows the average level of difference in agreement of the teachers and the students. This reveals that according to students there is no difference between the two and they face no such difficulty while reading a text. On the other hand, in statement 10 students were asked about relevancy between pronunciation and spellings of words in English language. The mean score 2.61 shows the average level of agreement of the teachers and students on the same statement.

Table No. 4

Perception of Students toward English Pronunciation

\begin{tabular}{|c|c|c|c|}
\hline $\begin{array}{l}\text { Sr. } \\
\text { No. }\end{array}$ & Students' opinions & $\begin{array}{l}\text { Mean } \\
\text { Scores }\end{array}$ & Level \\
\hline 1 & $\begin{array}{l}\text { Teachers should make students practice how to } \\
\text { speak English as native speakers do. }\end{array}$ & 4.78 & Highest \\
\hline 2 & $\begin{array}{l}\text { If students pronounce English incorrectly while } \\
\text { they practice, teachers should correct their } \\
\text { mistakes. }\end{array}$ & 2.76 & Average \\
\hline 3 & $\begin{array}{l}\text { The teachers should teach the students how to } \\
\text { stress words. }\end{array}$ & 2.40 & Average \\
\hline 4 & $\begin{array}{l}\text { The teachers should teach the students about } \\
\text { sentence intonation. }\end{array}$ & 4.31 & Higher \\
\hline 5 & $\begin{array}{l}\text { The teachers should use minimal pairs while } \\
\text { teaching pronunciation. }\end{array}$ & 4.26 & Higher \\
\hline 6 & $\begin{array}{l}\text { The teachers should use tongue twisters while } \\
\text { teaching pronunciation. }\end{array}$ & 4.30 & Higher \\
\hline
\end{tabular}




\begin{tabular}{|c|c|c|c|}
\hline 7 & $\begin{array}{l}\text { Pronouncing English sounds correctly can lead } \\
\text { students to efficient communication. }\end{array}$ & 3.83 & Higher \\
\hline 8 & $\begin{array}{l}\text { Teachers should use communicative activities } \\
\text { for EFL learners }\end{array}$ & 2.61 & Average \\
\hline 9 & $\begin{array}{l}\text { The teachers should use classroom language } \\
\text { such as "excellent"," well-done" and "repeat } \\
\text { after me" etc. }\end{array}$ & 1.38 & Lowest \\
\hline 10 & $\begin{array}{l}\text { Activities given in course books can encourage } \\
\text { students to practice English for communication. }\end{array}$ & 2.32 & Lower \\
\hline
\end{tabular}

Statement 1 in table 4 is to extract out the perceptions of students that teachers' should make students practice to speak like native speakers and its mean score is 4.78 . The perceptions of the students show the highest level of agreement on the statement according to the levels of opinion. The result reveals that practice is very important in order to learn accurate pronunciation. So teachers should make them practice and develop interest in them for learning English pronunciation. Derwing and Munro (2003) are of the view that teachers' role is to aim at actual life objectives for teaching pronunciation to aid EFL learners'. The statement 2 is to gauge the perceptions of students that teachers should correct their mistakes while practicing. The mean score 2.76 shows the gap of difference in the level of agreement with the mean score of 1.00 of students with the teachers on the same statement. The students were of the view that inaccurate pronunciation is very common at their secondary level and that usually the teachers' pronunciation is not accurate. The mean scores of question $3,4,5$ and 6 asking students that teacher should teach the students how to stress words, about intonation, use of minimal pairs and use of tongue twisters are 2.40, 4.31, 4.26 and 4.30 respectively which shows lower, higher and highest level of agreement of the students. The 
students seem (and questionnaire reveal) more confident and enthusiast in terms of their own pronunciation. This mean score reveals that students point out that in this field of learning pronunciation the guidance and support of a teacher is the leading step. The mean scores of teachers for the item $3,4,5$ and 6 were $2.40,3.31,3.26$ and 2.30. These means scores were different as compared to the mean scores of students showing the difference in perceptions between the teachers and the students on the same statement. The result shows the students' positive attitude towards learning English language. According to Lu (2002) learners need assistance in learning pronunciation to overcome as well as get rid of the entire problem. Some students lack motivation and self-confident in the course of developing effective communication. This view point is supported by question 7 asking if pronouncing in the approved manner can pave the way in developing understanding in the course of communication. The mean score of the statement is 1.83 . Thus having the difference in level of agreements between the teachers and the students with the mean score 2.00. This shows that students having no background with efficient communication in accurate pronunciation were feeling hesitation and problems in learning the sounds of pronunciation. The result reveals the fact that it's the duty of teacher to develop confidence and learning power in students so that they can communicate proficiently in English language with correct pronunciation to develop and strong their social relations. When the students were asked in statement 8 , that teachers should use communicative activities for EFL learners, they show the average level of agreement with the mean score 2.61, and the difference in perceptions of teachers with the mean score of 1.00 . The results reveal that due to discouragement by the other class fellows students were very passive and showing less interest as compare to teachers. Students think that communication in Urdu language is more convenient as compared to English, and they feel easy to communicate in Urdu language outdoor the classroom. The statement 9 is to find out the perceptions of students that teachers should use 
classroom language English word substitutions such as "repeat after me" etc. The mean score 1.38 obtained from the data shows the lowest level of agreement of students on the statement with the difference of mean score 2.00 on the ninth item with the perceptions of teachers on the statement. The result reveals that students seem least interested in using English language in classroom. The reason is that they were facing difficulties in learning second language after passing the neurological period of their age. The last item of this table is to explore the perceptions of students' with the mean score of 2.32. This shows the lower level of agreement of students on the statement as compared to teachers showing higher level of agreement on the same statement. The result reveals that the reason behind this disagreement is insufficient background knowledge in English language and inadequate vocabulary. The students seem too interested and agree with the idea of combining the communicative activities with course book activities. They want their teachers to guide them and show their part actively in these healthy activities because they know the importance of practice provided by these activities. They want to learn English language but with the help of their teachers. So, it is concluded that students need training explicitly in the production, articulation and recognition of the speech sounds.

\section{Conclusion}

Students in Pakistan lack self-confident, they delay in answering and are afraid of giving their opinions in English. They are passive in asking help for improving their English language. They show their negative attitudes towards learning English because their only reason for learning English is to earn passing marks for the examination and they do not consider it necessary to use English language outside the classroom. They do not pay attention and do not try to speak English language. 
The conclusion of the study was drawn from the findings of the results of the study. It was concluded with the help of the results of the three set objectives of the study that the importance of teaching and learning of English pronunciation should not be ignored. Information related to communicative fluency and Phonological accuracy should be introduced at Intermediate level in the classroom. The results of this study throws light on the practical implications of the methods and techniques used in teaching and learning pronunciation which will provide benefit to both teachers and students.

1. Teachers should first polish and update their knowledge according to the present modern era and should provide opportunities to the students to actively participate in the classroom activities as well as outdoor the classroom.

2. Teachers should acknowledge the students in solving the problems in the course of learning pronunciation. The four skills reading, listening, writing and speaking should be used in the teaching and learning of pronunciation. 'Listen and repeat' technique should be used.

3. Students should made practice so that all the hesitation will be removed and it will result in developing motivation and self-confident in the speaker. It's the duty of the head of the institution to provide all the gadgets for the proper teaching of pronunciation in the English language learning classes.

4. Audio-Visual aids, computers and talking dictionaries should be used by the teachers and the students. Pronunciation should be included as a subject in the course at the Intermediate level so that the students can produce immediate communication and represent themselves as a literate member of the society in front of the native and nonnative English language speakers. 


\section{References}

Avery, Pete,. \& Ehrlich Susan. Teaching American English Pronunciation. New York, NY: Oxford University Press. (1992).

Cenoz, Jasone, and Ma Luisa Garcia Lecumberri. "The acquisition of English pronunciation: Learners' views." International Journal of Applied Linguistics 9.1 (1999): 3-15.

Celce-Murcia, Marianne, Donna M. Brinton, and Janet M. Goodwin. Teaching pronunciation: A reference for teachers of English to speakers of other languages. Cambridge University Press, 1996.

Chomsky, Noam. Language and Mind. New York: Harcourt Brace Jovanovitch. 1972 Crystal, David. English as global language. Cambridge: Cambridge University Press. (1997). Derwing, Tracey M., Murray J. Munro, and Grace Wiebe. "Evidence in favor of a broad framework for pronunciation instruction." Language learning 48.3 (1998): 393-410.

Esmail, Asma, Mumtaz Ahmed, and Sadia Noreen. "Why do Pakistani students are reluctant to speak English." Acad. Res. Int 6.3 (2015): 372-383.

Gatbonton, Elizabeth, Pavel Trofimovich, and Michael Magid. "Learners' ethnic group affiliation and L2 pronunciation accuracy: A sociolinguistic investigation." TESOL quarterly 39.3 (2005): 489-511.

Goswami, Jaya S., and H. U. Chen. "The impact of instruction in phonetic and phonemic distinctions in sounds on the pronunciation of Spanish-speaking ESL learners." Mextesol Journal 34.1 (2010): 29-39.

Graham, J. (1994). "Four Strategies to Improve the Speech of Adult Learners" . TESOL Journal, 3(3), 26-28.

Graham, Janet G. "Four Strategies to Improve the Speech of Adult Learners." TESOL Journal 3.3 (1994): 26-28. 
Howlader, Mohammad Rasel. "Teaching English pronunciation in countries where English is a second language: Bangladesh perspective." ASA University Review 4.2 (2010): 233-244.

Kang, Okim. "ESL learners' attitudes toward pronunciation instruction and varieties of English." Proceedings of the 1st Pronunciation in Second Language Learning and Teaching Conference. Ames, IA: Iowa State University. 2010.

Khamkhien, Attapol. "Thai Learners' English Pronunciation Competence: Lesson Learned from Word Stress Assignment." Journal of Language Teaching \& Research 1.6 (2010).

Krashen, Stephen. "Principles and practice in second language acquisition." (1982).

Likitrattanaporn, Wannakarn. "Teaching Phonological Accuracy and Communicative Fluency at Thai Secondary Schools." English Language Teaching 7.2 (2014): 1-10.

Lu, Dan. "Phonetic Symbols: A Necessary Stepping Stone for ESL Learners." Forum. Vol. 40. No. 4. http://exchanges. state. gov/forum/, 2002.

Major, Roy C. "Measuring pronunciation accuracy using computerized techniques."Language Testing 4.2 (1987): 155-169.

Marinova-Todd, Stefka H., D. Bradford Marshall, and Catherine E. Snow. "Three misconceptions about age and L2 learning." TESOL quarterly 34.1 (2000): 9-34. Morley, Joan. "The pronunciation component in teaching English to speakers of other languages." TESOL quarterly 25.3 (1991): 481-520.

Moyer, Alene. "Do language attitudes determine accent? A study of bilinguals in the USA." Journal of Multilingual and Multicultural Development 28.6 (2007): 502-518.

Rajadurai, Joanne. "An investigation of the effectiveness of teaching pronunciation to Malaysian TESL students." Forum. Vol. 39. No. 3. 2001. 
Warsi, Jilani. "Conditions under which English is taught in Pakistan: An applied linguistic perspective." Sarid Journal 1.1 (2004): 1-9.

Wenk, Brian J. "Speech rhythms in second language acquisition." Language and speech 28.2 (1985): 157-175. 